\title{
A Text Mining Approach in Patents and Papers: Analyzing Wind and Solar Energy Trends
}

\author{
Cleber Gustavo Dias \\ Informatics and Knowledge Management Graduate Program \\ Nove de Julho University - UNINOVE \\ So Paulo - Brazil
}

\author{
Alaydes Mikaelle de Morais \\ Informatics and Knowledge Management Graduate Program \\ Nove de Julho University - UNINOVE \\ So Paulo - Brazil
}

\begin{abstract}
Renewable energies have become extremely relevant assets for many countries during the past years. More particularly, some research institutions and companies around the world have invested efforts and significant resources to foster new technical solutions and scientific discoveries in two of the most important areas in renewable developments, such as wind and solar energy. Therefore, this paper presents a technological trajectory analysis in both fields, using text-mining techniques in granted patent and patent application documents from 2010 until 2019 and papers published by IEEE Xplore Digital Library, considering the same period. The IEEE library has more than 5 million items and the World Intellectual Property Organization database has around 84 million patent documents. The Rstudio software was used for text-mining purposes in the abstracts and other text information for both repositories. The present research has processed 68064 patents documents for wind energy and 59224 patents documents for solar energy. Moreover, more than 13158 papers have been processed for wind and solar energy during the aforementioned period. The results have shown not only the state of the art about the technologies developed by inventors and patent applicants, but also potential trends of the distinct stakeholders on each type of renewable energy.
\end{abstract}

\section{Keywords}

Solar Energy, Wind Energy, Technology Trends, Patent Analysis, Technology Trajectory

\section{INTRODUCTION}

Renewable Energies are experiencing an impacted growth. As resources that are naturally replenishing but flow limited, and virtually inexhaustible in duration but limited in the amount of energy that is available per unit of time [1], renewable energy sources minimize environmental impacts, and once they are considered as clean sources of energy it is possible to consider that they produce minimum secondary wastes and are sustainable based on current and future economic and social needs [2].

In the United States, in mid-2019, renewable energy sources provide only about eleven percent of the electricity in the country's grid [3]. However, high penetration of renewable energy is becoming a trend and researchers have shown that supplying all the energy needs of the United States from it could be achievable in the future [4]. The National Renewable Energy Laboratory - NREL suggested that in 2050 renewable energy potentially will support about 80 percent of the total electricity consumption in the U.S. [5]. China, following the same path, has a goal to generate 85 percent of electricity from renewable sources in 2050 [6].

Across the world, it is possible to find government agencies and institutes working to find, study and improve most of renewable energies. The U.S. Energy Information Administration - EIA, International Renewable Energy Agency - IRENA, National Energy Administration - NEA in the U.S. and China National Renewable Energy Centre - CNREC are some examples of such governmental bodies. They encourage, promote and enrich researchers who are looking for renewable energy data [7]. More particularly, wind and solar power are the leaders when the topic is a clean source of energy, companies and countries are running to understand, study and get more information and knowledge to produce more with less and to avoid non-renewable, more traditional energy sources such as Oil [8].

There is a growing body of literature that recognizes the importance of renewable energies around the globe. However, much uncertainty still exists about the relation between those studies in different areas of interest, such as scientific manuscripts and patent documents. Moreover, how governments, industry and universities are working at the same subjects in and highlight points where those could work together.

A patent is an exclusive right granted that can be applied, in general, when someone finds a new way of doing something, or offers a new technical solution to a problem. If the inventor wants to get that right, technical information about the invention must be disclosed to the public in a patent application that will be hold in a patent database [9]. That information helps others to know what is new, avoid duplication of work; also, it protects the original author of the invention if someone tries to use his protected rights.

Patents can be created for a number of reasons, for example to support the researchers and their research in case it evolves into a profitable product. Others are created with that goal in mind: having a commercial application of a technology or technique. In addition, patents help universities, industries and even governments who are interested in protect their new technologies, processes and methods [10]. The World Intellectual Property Organization - WIPO has the biggest International Patent System, which is ruled by the Patent Cooperation Treaty - PCT, then, WIPO holds patent applications from most countries and has around 84 million patent documents, including 3.8 million published international patent appli- 
cations. It is from there that this research got part of renewable energies information.

One of the important journal databases in the renewable energy sources field is the Institute of Electrical and Electronics Engineers - IEEE, which is a nonprofit institution based in the US and it is one of the biggest organizations dedicated to improve technological advance and to help humanity with its issues [11]. IEEE is a reliable source for international researchers and because of that, it was chosen as the source for searching information related to renewable energies in this work.

Based on the aforementioned, this paper presents an analysis between the years of 2010 to 2019, of renewable energies studies focusing on wind and solar power in journals and patent documents, looking primarily to the amount of each in both data sources in each year.

This research intends to contribute and offer for the community in general a better understanding of correlations of what is being studied between universities, industry and government. Trying to answer how different kinds of research are working with renewable energies across the world and why those energies are in the center of knowledge research right now. Therefore, the present work intends to answer some questions related to the investments and use of wind and solar power around the world, considering different kind of players in the past decade.

In this sense, this study is not only focused on understanding the state of the art for such technologies, but also highlight potential trends of the distinct stakeholders on each type of renewable energy.

Among the questions answered by this work, it can be highlighted: i-) the relation between papers and patents based in both renewable energies searched, such as wind and solar energy; ii-) And how those researchers and patent applicants are working with those different types of energy over half a decade, based in those results; and iii-) also, this paper wants to bring into evidence a correlation based in a quantitative study grounded in a text mining investigation of words from journals and patents cross years, energy and source of study.

\section{THEORETICAL BACKGROUND AND RELATED WORKS}

\subsection{The International Patent System}

The work published by [12] defines a Patent as a document, that grants the right to exclude anyone else from the production or use of a specific new device, apparatus, or process for a stated number of years. It is issued by an authorized governmental agency only after an examination focused on novelty and inventive step of the claimed object and its potential utility.

WIPO, previously defined in the introduction of this paper, holds most of patent applications in the globe in their International Patent System. It has over 150 Contracting States based in its PCT as noted in [13]. He also informs that the PCT helps inventors when they want a Patent protection in a large number of countries, simultaneously, by filing a single international patent application. It is an international treaty that has national and international phases to seek and skip the obligation of filing several separate national or regional patent applications [13]. In the PCT system, the inventor applies in a patent office just once, and the application is transmitted to the international authorities and published in the PatentScope, i.e., a patent search tool that allows user to search for patents in the WIPO database.

\subsection{Text-mining techniques to extract textual information}

As cited in [14], the text-mining procedures typically involve the feature extraction of a text in a spreadsheet format. In general, the text source is an unstructured data and some techniques should be done to obtain the features commonly generated from text.

Basically, the text-mining techniques can be divided into some steps, such as described as follows: i-) Collecting Documents: in this first step the data should be collected from the relevant documents according to the problem description; ii-) Document Standardization: in this second step the documents collected in the previous step could be in a variety of different formats, depending on how the documents were generated, thus, it is necessary to convert them to a standard format; iii-) Tokenization: in this third step the handling text is applied to break the stream of characters into words or, tokens. This is an important step to extract higher-level information from the document [14]; iv-) Stemming or lemmatization: in this step could be necessary to convert each of the tokens to a standard form, in order to eliminate some forms of the same word before further processing, i.e., to normalize both words to the single form, including grammatical variants such as singular/plural and present/past cases.

The collective set of features, or words, is typically called a dictionary [14]. In some cases reduction techniques are also used to reduce the size of the dictionary, such as the compilation of stopwords to remove and the use of frequency information on the words that can be quite useful in reducing dictionary size. In this sense, the most frequent words are often stopwords and can be deleted. Obviously, the remaining most frequent used words are often the important words that should be remained in a local dictionary [14][15].

\subsection{Related works of patent-based documents and papers for information extraction in renewable energies}

The importance of a patent study is validated with relevant and scientific reports as presented in [16]. In this case, authors looked at the state of the art and brought to the academic community a different point of view about the use of that type of information and its applications in the scientific cycle.

The work published by [17] also connects patents to clarify trends and determinants of energy innovations. In that paper it is suggested that a discussion about a decrease in the number of energy patenting should be made, targeting a reduction of Oil price. In [18], a comprehensive overview of the evolution of a specific type of eco-innovations is proposed, namely low-carbon energy technologies using patent document analysis. Other works addressed the use of patent citation networks to study the dynamics of some technical issue and identify its technological development, including, for example, mapping technological trajectories of crystalline silicon $\mathrm{PV}$, data communication standards and energy storage devices [19][22]. In other studies, a patent landscape analysis was provided to identify the technological development of photovoltaic cells [23][24].

Papers showing renewable energy trends and how the world is working with that theme in the academic universe were found. In [25], for example, the authors shown a review of the progress made in solar power generation research and development since its inception and a comprehensive review of the state of the art of wind energy conversion systems and technologies has been proposed in [26].In [27], it has a recent and another important exam- 
ple, this study highlights which countries publish more about renewable energies, which kind of renewable energy is on focus at the moment and the academic cooperation between the U.S., China and the E.U., while also pointing that there still is much to study about this. Recently, it is important to mention that, the patent documents have also been used to evaluate other energy technological fields, as the solutions disclosed by [28] and [29].

Therefore, the aforementioned works usually addressed patent documents or scientific manuscripts to extract valuable information and better understand the technological evolution of some renewable energies. In a distinct way, the present research has performed text-mining procedures in abstracts for both patents and papers, in order to evaluate some technological trends in wind and solar energy during the last decade. In a previous study, the authors have published initial results in the Brazilian Sodebras Conference [30], but only applying text mining techniques in patents database to evaluate the technological trajectory in wind energy field during the last decade.The next section shows the present approach and mains steps carried out during the study.

\section{METHODS AND THE METHODOLOGY}

The main objective of this paper is to quantify and correlate, amongst patents and papers, how prominent is the theme of renewable energies. To achieve this objective a quantitative and qualitative research method will be used. Quantitative research methods are more adequate when a large data set is available, such as the one resulting from the initial data extraction of this research. Qualitative research methods are designed to help reveal the behavior and perception to a particular topic, in this case topics related to renewable energies.

For a trend analysis purposes, in wind and solar energy, this research has applied some text-mining techniques in abstracts of granted patent and patent application documents from 2010 until 2019 and abstracts of papers published by IEEE Xplore Digital Library, considering the same period. As mentioned before, the IEEE library has been chosen due to the large size of its database, including wind and solar researches and patents have been retrieved from the WIPO data, since its repository has more than 80 million patent documents. In addition, these data sources were selected because these are generally considered as reputable sources and provide easy to use tools to search and extract data. Therefore, the present methodology, for patents and papers information extraction, has been carried out using the main text-mining methods [14] and it consists of six stages as shown in Figure 1.

Each stage can be summarized as follows: stage 1 and stage 2 are related to the collecting documents and standardization methods, since articles and patents abstracts have been retrieved and data have been distributed by year of interest. The files have been processed from text files (.csv format) in stage 3 and text-mining packages have been loaded into R software. In stage 4, the tokenization and lemmatization are applied, after that it is possible to collect a dictionary in stage 5. That process was made for each renewable energy data extracted from IEEE and WIPO. After that, in stage 6 it is possible to compare the dictionary in each renewable energy field and database and correlate them.

\section{RESULTS AND DISCUSSIONS}

This section summarizes the results obtained from text mining of abstracts using the patents documents and papers. Therefore, this section is divided into three subsections, as follows: i-) Data retrieved from WIPO patents; ii-) Data retrieved from IEEE papers

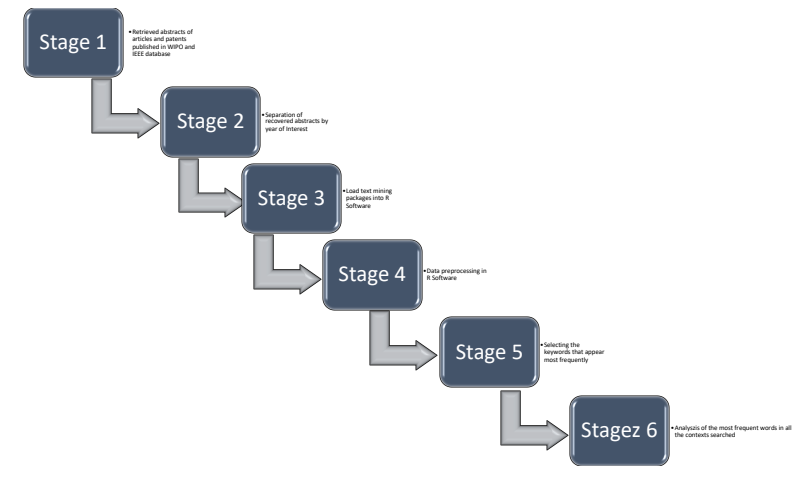

Fig. 1: Main stages used in the present methodology

database; and iii-) Cross analysis from WIPO patents x IEEE scientific articles.

\subsection{Results obtained from WIPO patents}

The first analysis, extracted from WIPO patents database, it was possible to identify frequent words that are repeated year by year in the course of a decade, it in both searches, i.e., solar and wind power, as shown in Table 1, Table 2 and Table 3. In Table 1, it is possible to verify that seven words keeping appearing each year during the decade searched, considering the results retrieved from Wind Power terms.

Looking to the first year, 2010, and the last one, 2019, all those words increase frequency, giving a strong suggestion that, in those subjects, inventors still going at the same path looking for air, blade, connected, control, device, generation and generator. A careful reading about patent abstracts allows us to observe that some frequent words are applied for solving particular technical problems. For example, the word blade is related to inventors and applicants whose concern is about the design of wind turbine rotor blades and how to improve its aerodynamic performance (Table 2). In most cases, the patents disclose some blade apparatus, devices and methods to construct and/or install its structure. Therefore, the words device and connected, for example, are quite cited in the patent abstracts due to the connection of the portions commonly found during the construction of a wind rotor. The word control is frequently associated to other words, such as pitch and shaft, since the inventors have developed technologies to improve the pitch control of the blade pitch angle, for example.

When the study is about Solar Power, it is possible to suggest the same affirmation, looking at Table 3, twelve words showed up each year.

An important finding it is that five words are present in both searches and in all ten years, and it strongly points a correlation between inventors in solar and wind power field of study over a decade. Approaching more the results to look at the applicants, for example, who will be the owner of the invention, Table 4 and Table 5 disclose some interesting information about the top ten companies on each energy sector.

It is possible to observe that, two applicants are present in both lists, General Electric Company and Siemens Aktiengesellschaft, which indicates that companies that are patenting are interested in both renewable energies in those years searched too. Illustrating 
Table 1. : Frequent words that repeat from 2010 to 2019. Wind Power Search on WIPO database

\begin{tabular}{|c|c|c|c|c|c|c|c|c|c|c|}
\hline & \multicolumn{10}{|c|}{ Year } \\
\hline Word & 2010 & 2011 & 2012 & 2013 & 2014 & 2015 & 2016 & 2017 & 2018 & 2019 \\
\hline air & 1437 & 1907 & 1838 & 1597 & 1799 & 2334 & 1818 & 3088 & 4916 & 8862 \\
\hline blade & 2390 & 2709 & 2807 & 2769 & 2545 & 2953 & 2306 & 3712 & 4665 & 5576 \\
\hline connected & 1877 & 2292 & 2442 & 2253 & 2815 & 3974 & 2957 & 5006 & 7444 & 10207 \\
\hline control & 1665 & 2104 & 2693 & 2660 & 3072 & 3754 & 3430 & 5009 & 6206 & 6309 \\
\hline device & 2601 & 3456 & 3701 & 3207 & 4194 & 5929 & 4562 & 7790 & 11154 & 16109 \\
\hline generation & 1857 & 2541 & 2878 & 2623 & 3598 & 4830 & 4447 & 7340 & 10137 & 9520 \\
\hline generator & 3598 & 4081 & 3981 & 3893 & 3784 & 4241 & 3187 & 4487 & 5690 & 6165 \\
\hline & \multicolumn{10}{|c|}{ Frequency } \\
\hline
\end{tabular}

Table 2. : Some recent wind energy patents documents which word blade was often cited

\begin{tabular}{|l|l|l|l|l|}
\hline \multicolumn{1}{|c|}{$\begin{array}{c}\text { Patent } \\
\text { Aplication Id }\end{array}$} & \multicolumn{1}{|c|}{ Title } & \multicolumn{1}{c|}{ Country } & \multicolumn{1}{c|}{ IPC } & \multicolumn{1}{c|}{$\begin{array}{c}\text { Application } \\
\text { Date }\end{array}$} \\
\hline WO2019209313 & $\begin{array}{l}\text { Tip extensions for wind turbine rotor } \\
\text { blades and methods of installing same }\end{array}$ & WO & $\begin{array}{l}\text { F03D 1/06; } \\
\text { F03D 80/30 }\end{array}$ & $27 / 04 / 18$ \\
\hline US275482224 & $\begin{array}{l}\text { Joint for connecting a wind turbine } \\
\text { rotor blade to a rotor hub and asso- } \\
\text { ciated methods }\end{array}$ & United States & F03D 1/06 & $13 / 12 / 17$ \\
\hline WO2019210330 & $\begin{array}{l}\text { Flexible wind turbine blade with ac- } \\
\text { tively variable twist distribution }\end{array}$ & WO & $\begin{array}{l}\text { F23D 1/06/; } \\
\text { F03D 7/02 }\end{array}$ & $29 / 04 / 19$ \\
\hline CN276202370 & $\begin{array}{l}\text { Fan blade assembly structure for new } \\
\text { energy wind power generation }\end{array}$ & China & F03D 13/10 & $25 / 02 / 19$ \\
\hline CN276141839 & $\begin{array}{l}\text { Glue blocking device, blade and blade } \\
\text { forming method }\end{array}$ & China & F03D 1/06 & $20 / 06 / 19$ \\
\hline
\end{tabular}

Table 3. : Frequent words that repeat from 2010 to 2019. Solar Power Search on WIPO database

\begin{tabular}{|c|c|c|c|c|c|c|c|c|c|c|}
\hline & \multicolumn{10}{|c|}{ Year } \\
\hline Word & 2010 & 2011 & 2012 & 2013 & 2014 & 2015 & 2016 & 2017 & 2018 & 2019 \\
\hline battery & 1009 & 1425 & 1612 & 1723 & 1748 & 2688 & 1986 & 3188 & 4028 & 4498 \\
\hline cell & 1428 & 1723 & 1905 & 1653 & 1611 & 2180 & 2020 & 2181 & 2739 & 3168 \\
\hline connected & 1125 & 1248 & 1368 & 1551 & 1798 & 2741 & 2566 & 3602 & 4565 & 5998 \\
\hline control & 1208 & 1455 & 1811 & 1957 & 2188 & 2817 & 3074 & 3906 & 4217 & 4451 \\
\hline device & 2644 & 3066 & 3259 & 3230 & 4266 & 5406 & 5387 & 6881 & 9414 & 10421 \\
\hline generation & 1142 & 1548 & 1768 & 1846 & 1867 & 2687 & 2594 & 3791 & 5141 & 6683 \\
\hline module & 1129 & 1366 & 1478 & 1615 & 1722 & 2532 & 2339 & 3241 & 4201 & 5070 \\
\hline storage & 914 & 1257 & 1345 & 1486 & 2015 & 2622 & 2140 & 2719 & 3386 & 3944 \\
\hline unit & 1207 & 1691 & 2128 & 2411 & 2056 & 2242 & 2298 & 2980 & 3074 & 3133 \\
\hline water & 1393 & 1545 & 1595 & 1325 & 1617 & 1886 & 2249 & 3120 & 4139 & 4432 \\
\hline & \multicolumn{10}{|c|}{ Frequency } \\
\hline
\end{tabular}

year by year, WIPO website, PatentScope gives time series of all applicants as Figure 2 and Figure 3 elucidate, there it is possible to affirm that new applicants are arising as State Grid Corporation of China, that assumed the first position in 2014 and it is keeping it in the Wind Power scenario. Solar Power shows another relevant applicant, Suzhou Csi Solar Power Technology Co., Ltd., that got the first position only in 2017 and still there until 2018.

Table 6 presents the results related to Countries and/or Officers and revels that the top results are the same, Chine got the first position in
Wind search and US in Solar, but PCT and European Patent Office have the same position. It indicates that those ten Countries/Offices are investing in Solar and Wind Power research in those ten years. The IPC code is other important information retrieved from patent documents, since this code is related to the different areas of technology. These data have been recovered after processing the proposed text-mining techniques. Thus, in both scenarios, solar and wind, it was possible to note that it has some similarities, since 
Table 4. : Top ten applicants from 2010 to 2019. Wind Power Search on WIPO database

\begin{tabular}{|l|l|}
\hline Applicants & Frequency \\
\hline STATE GRID CORPORATION OF CHINA & 1,279 \\
\hline GENERAL ELECTRIC COMPANY & 1,195 \\
\hline VESTAS WIND SYSTEMS A/S & 714 \\
\hline WOBBEN PROPERTIES GMBH & 678 \\
\hline SIEMENS AKTIENGESELLSCHAFT & 589 \\
\hline MITSUBISHI HEAVY INDUSTRIES, LTD. & 545 \\
\hline MITSUBISHI HEAVY IND LTD & 427 \\
\hline GEN ELECTRIC & 422 \\
\hline HITACHI LTD & 334 \\
\hline HITACHI, LTD. & 327 \\
\hline
\end{tabular}

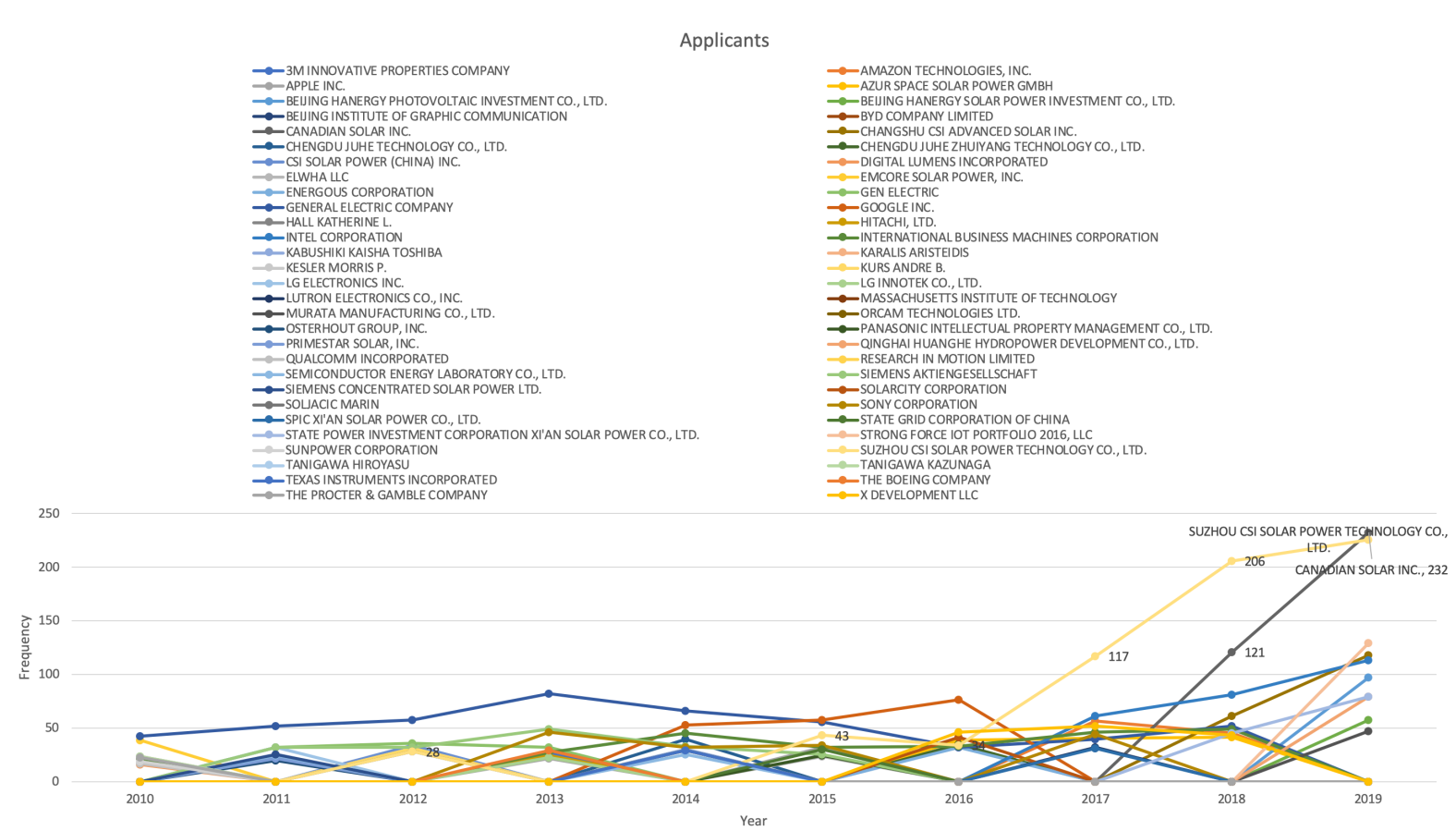

Fig. 2: Top applicants year by year. Wind Power Search on WIPO database

six codes are presented in Column Wind and in Column Solar, as shown in Table 7.,looking into a whole decade.

Dividing the results for year, as Figure 4 and Figure 5, it shows that the IPC codes line did not change a lot over the years in the Wind Scenario as Solar. While in Wind Power search the IPC Code F03D was the first position in all years, Solar Power has a new one each 2-4 years, that indicates that in one scenario has more constancy than the other.

The IPC code F03D is related to wind motors, which covers mechanisms for converting the energy of wind into useful mechanical power and the transmission of such power to its point of use. It is important to note that, in solar energy inventions, over the past 5 years, the applicants have investing efforts and resources in technologies related to the IPC codes H02S and H02J. These codes are related respectively to generation of electric power by conversion of infrared radiation, visible light or ultraviolet light, e.g, using photo- voltaic modules, and circuit arrangements or systems for supplying or distributing electric power.

\subsection{Results obtained from IEEE papers database}

By studying the IEEE paper abstracts and other journal information, it is possible to identify the publication title of all articles in both areas, solar and power energy, over a decade. The Publication title shows where the paper was published or, in other terms, which area of IEEE it was applied. When researchers are looking to write and publish an article, they lookup electronic journals, magazines, or newspapers and for that end, a publication title. By looking at the Publication title applied by the researchers choosing to write about solar and wind power, it is possible to find matches in the results. Understanding where other authors are focusing their effort when they are studying the same subject, solar and power, can help other researchers in their decision of which publisher they should apply 
APPLICANTS

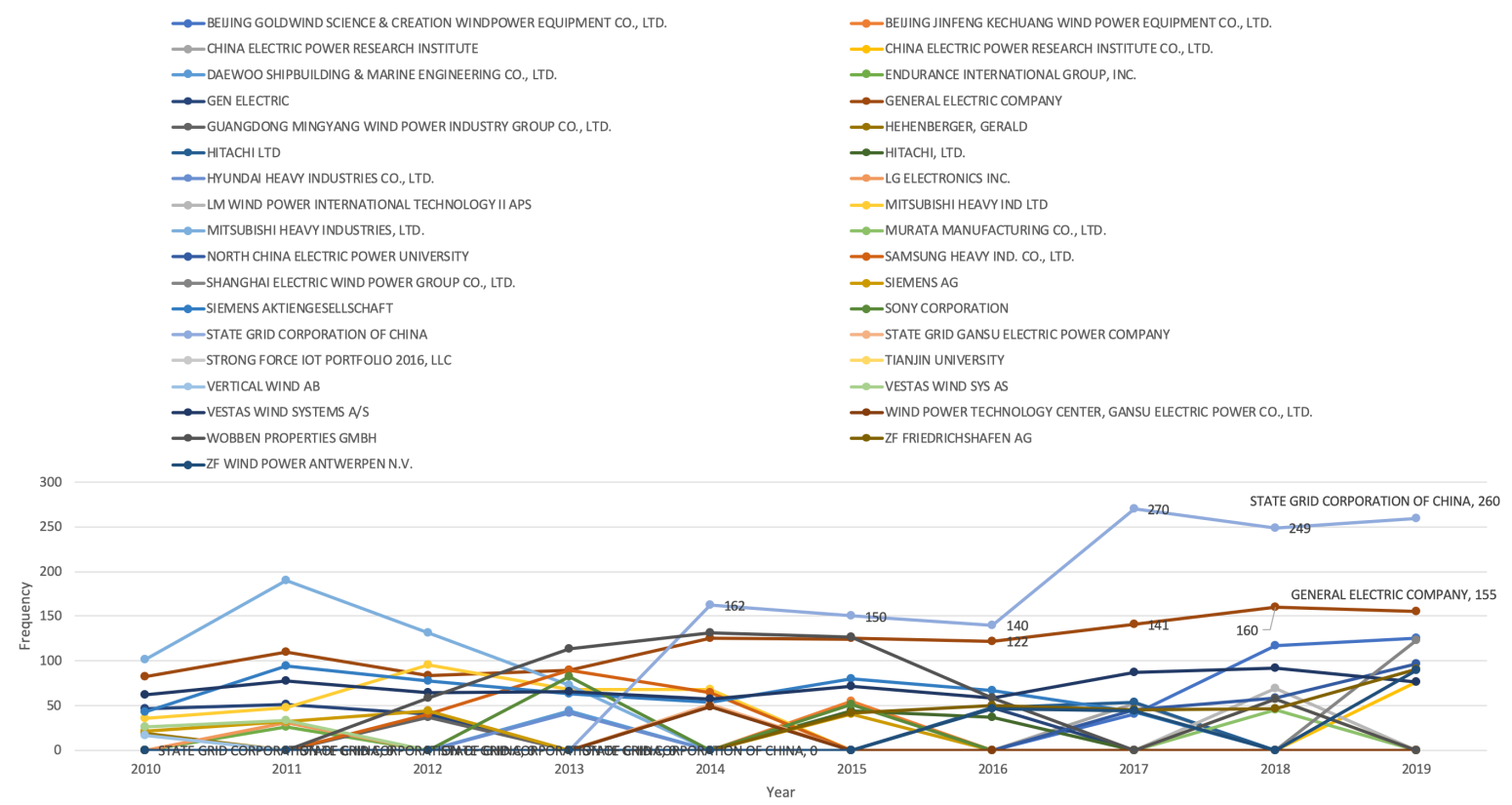

Fig. 3: Top applicants year by year. Solar Power Search on WIPO database

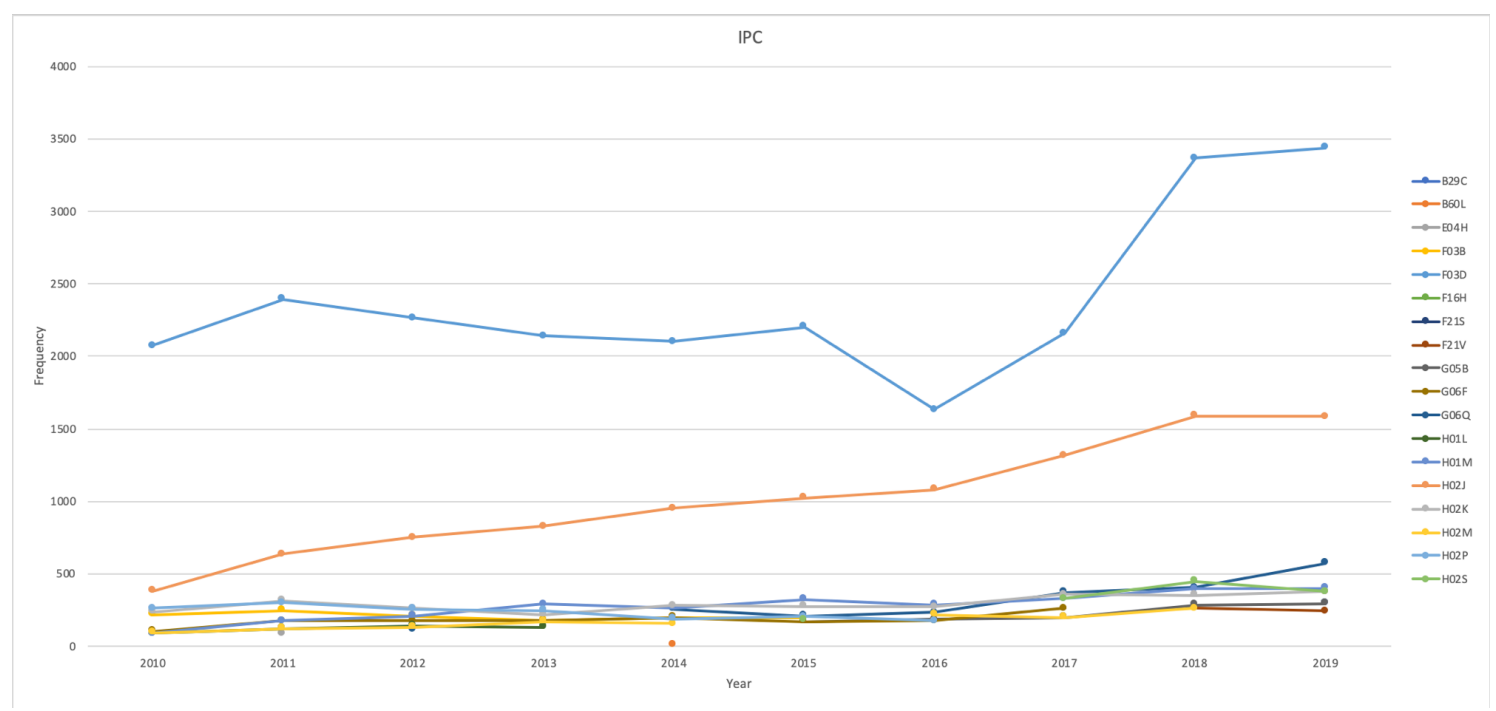

Fig. 4: Top IPC Codes year by year. Wind Power Search on WIPO database

or choose to reveal their findings. Over a decade, filtering the top twenty publication titles to solar and doing the same to wind search, Table 8 brings the information that from the forty results, just six in each column are not in the other column too. Leading to the understanding that researchers from both renewable energies are publishing at the same places.

Moreover, applying the text-mining techniques in the IEEE papers database it was possible to better understand the main research stakeholders. The results shown in Table 9 disclose the top ten Universities and Research Institutions, or Affiliations, which are work- ing in the both issues, i.e., solar and wind energy. For example, the Aalborg University in Denmark has an important contribution in wind and solar energy researches. As cited in [30], Aalborg University has be recognized as the 10 institutions most consistently cited as current leader in engineering education, including others such as Olin College of Engineering, Massachusetts Institute of Technology (MIT), Stanford University, among others.

The affiliation field, meaning the Educational and/or Research Institutions that are researching and applying to Journals in both renewable energies, has four similarities in the top ten listed, consis- 


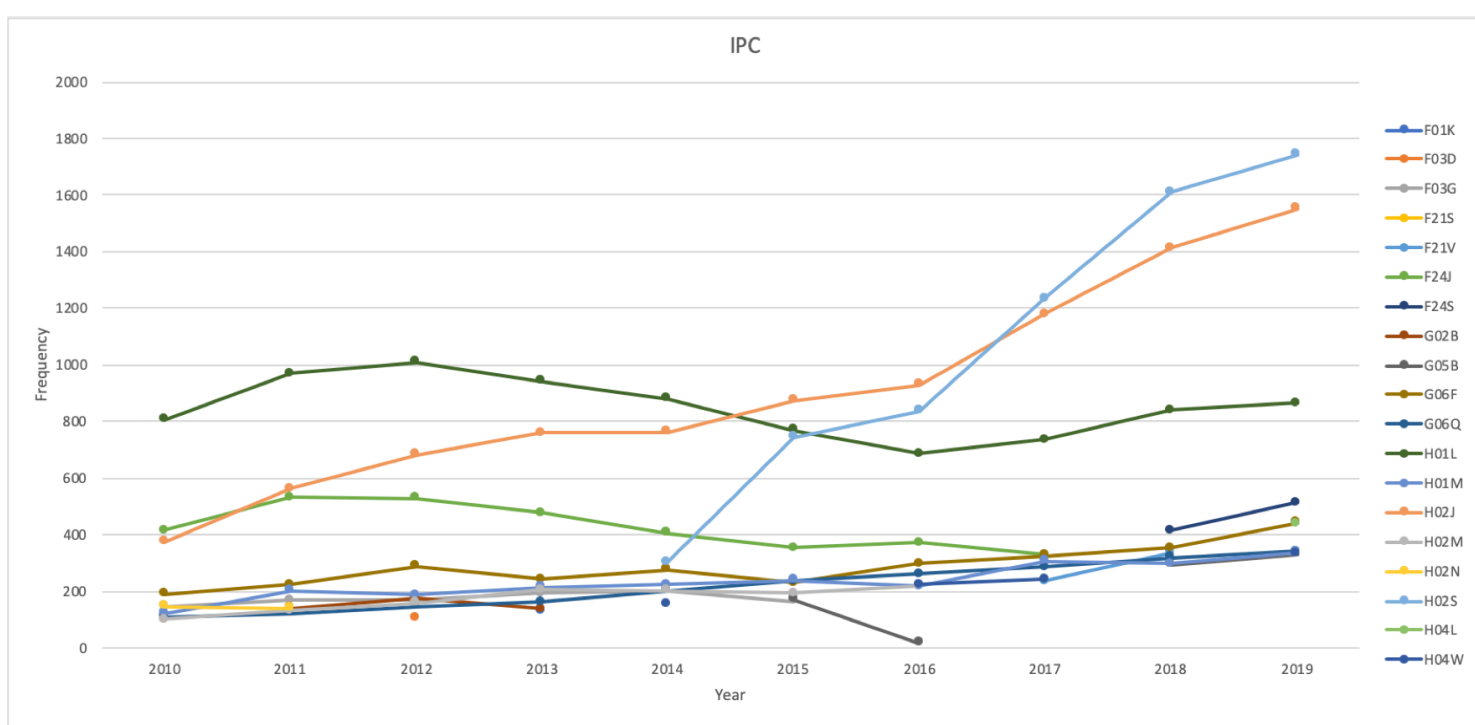

Fig. 5: Top IPC Codes year by year. Solar Power Search on WIPO database

Table 5. : Top ten applicants from 2010 to 2019. Solar Power Search on WIPO database

\begin{tabular}{|l|l|}
\hline Applicant & Frequency \\
\hline $\begin{array}{l}\text { SUZHOU CSI SOLAR POWER TECHNOLOGY CO., } \\
\text { LTD. }\end{array}$ & 645 \\
\hline GENERAL ELECTRIC COMPANY & 514 \\
\hline CANADIAN SOLAR INC. & 353 \\
\hline $\begin{array}{l}\text { INTERNATIONAL BUSINESS MACHINES CORPO- } \\
\text { RATION }\end{array}$ & 307 \\
\hline INTEL CORPORATION & 292 \\
\hline GOOGLE INC. & 246 \\
\hline SIEMENS AKTIENGESELLSCHAFT & 239 \\
\hline CHANGSHU CSI ADVANCED SOLAR INC. & 229 \\
\hline SONY CORPORATION & 229 \\
\hline APPLE INC. & 219 \\
\hline
\end{tabular}

tent with the discovery that wind and power are walking together in academic field. IEEE frequency words, as showed in Table 10 and Table 11, elucidate that in both cases, Wind and Power, researches have grown, each year, in specifics areas.

Observing the frequency of those words at the first and last year, it is possible to state that all words, in both tables, grow.

Five words appeared in both results, voltage, systems, model, generation and control. That information strongly indicates that during the period searched, solar and wind power researchers were working in paths with similarities. More particularly, it is possible to note that the words model and control, for example, appears as a frequent word in both energy sectors.

\subsection{Cross analysis from WIPO patents $x$ IEEE scientific articles.}

This subsection discloses some correlations between data extracted from WIPO patents and IEEE papers. As shown by Figure 6, in
Table 6. : Top ten Countries/Offices from 2010 to 2019. Solar and Wind Power Search on WIPO database

\begin{tabular}{|l|l|l|l|}
\hline \multicolumn{2}{|c|}{ Wind } & \multicolumn{2}{c|}{ Solar } \\
\hline \multicolumn{1}{|l|}{ Country/Office } & Frequency & Country/Office & Frequency \\
\hline China & 28,862 & $\begin{array}{l}\text { United States of } \\
\text { America }\end{array}$ & 23,854 \\
\hline $\begin{array}{l}\text { United States of } \\
\text { America }\end{array}$ & 15,545 & China & 12,876 \\
\hline PCT & 5,969 & PCT & 8,412 \\
\hline $\begin{array}{l}\text { European Patent } \\
\text { Office }\end{array}$ & 5,961 & $\begin{array}{l}\text { European Patent } \\
\text { Office }\end{array}$ & 4,479 \\
\hline Republic of Korea & 3,968 & Australia & 2,731 \\
\hline Japan & 1,815 & Republic of Korea & 2,056 \\
\hline Australia & 1,698 & Canada & 1,324 \\
\hline Canada & 1,358 & Japan & 1,012 \\
\hline India & 591 & United Kingdom & 687 \\
\hline United Kingdom & 435 & India & 671 \\
\hline
\end{tabular}

the past decade there was an important growth of technologies protected by patents and those published by scientific manuscripts. The solar power researches found in papers had a relative growth greater than wind power discoveries, but in absolute numbers wind power solutions is greater when compared to solar power technologies in papers and patents, as shown in Table 12.

Comparing what was extracted from Wind Power and Solar Power, separately, looking at WIPO and IEEE, in those 10 years, the result is Table 13 and Table 14:

In the wind field, eight words, highlighted in the table, appears in both columns, WIPO and IEEE. This indicates a potential corre- 
Table 9. : Top ten Affiliations from 2010 to 2019. Solar and Wind Power Search on IEEE database

\begin{tabular}{|c|c|c|c|}
\hline \multicolumn{2}{|l|}{ Wind } & \multicolumn{2}{|l|}{ Solar } \\
\hline Affiliation & Frequency & Affiliation & Frequency \\
\hline $\begin{array}{l}\text { Aalborg University, Aal- } \\
\text { borg, Denmark }\end{array}$ & 107 & $\begin{array}{l}\text { Indian Institute of Tech- } \\
\text { nology Delhi, New Delhi, } \\
\text { India }\end{array}$ & 107 \\
\hline $\begin{array}{l}\text { Southeast University, } \\
\text { Nanjing, China }\end{array}$ & 73 & $\begin{array}{l}\text { Aalborg University, Aal- } \\
\text { borg, Denmark }\end{array}$ & 38 \\
\hline $\begin{array}{l}\text { Zhejiang University, } \\
\text { Hangzhou, China }\end{array}$ & 64 & $\begin{array}{l}\text { National Renewable En- } \\
\text { ergy Laboratory, Golden, } \\
\text { CO, USA }\end{array}$ & 38 \\
\hline $\begin{array}{l}\text { North China Electric } \\
\text { Power University, Peo- } \\
\text { ple's Republic of China }\end{array}$ & 62 & $\begin{array}{l}\text { National University of } \\
\text { Singapore, Singapore }\end{array}$ & 21 \\
\hline $\begin{array}{l}\text { Tsinghua University, Bei- } \\
\text { jing, China }\end{array}$ & 59 & $\begin{array}{l}\text { University of Waterloo, } \\
\text { Waterloo, ON, Canada }\end{array}$ & 18 \\
\hline $\begin{array}{l}\text { Huazhong University of } \\
\text { Science and Technology, } \\
\text { Wuhan, China }\end{array}$ & 57 & $\begin{array}{l}\text { Nanyang Technological } \\
\text { University, Singapore }\end{array}$ & 30 \\
\hline $\begin{array}{l}\text { China Electric Power Re- } \\
\text { search Institute, People's } \\
\text { Republic of China }\end{array}$ & 51 & $\begin{array}{l}\text { National Institute of } \\
\text { Technology, India }\end{array}$ & 15 \\
\hline $\begin{array}{l}\text { Tsinghua University, Peo- } \\
\text { ple's Republic of China }\end{array}$ & 44 & $\begin{array}{l}\text { Sandia National Labora- } \\
\text { tories, Albuquerque, NM, } \\
\text { USA }\end{array}$ & 15 \\
\hline $\begin{array}{l}\text { National Renewable En- } \\
\text { ergy Laboratory, Golden, } \\
\text { CO, USA }\end{array}$ & 40 & $\begin{array}{l}\text { National University of } \\
\text { Singapore, Singapore }\end{array}$ & 14 \\
\hline $\begin{array}{l}\text { Nanyang Technological } \\
\text { University, Singapore }\end{array}$ & 38 & $\begin{array}{l}\text { Zhejiang University, } \\
\text { Hangzhou, China }\end{array}$ & 12 \\
\hline
\end{tabular}

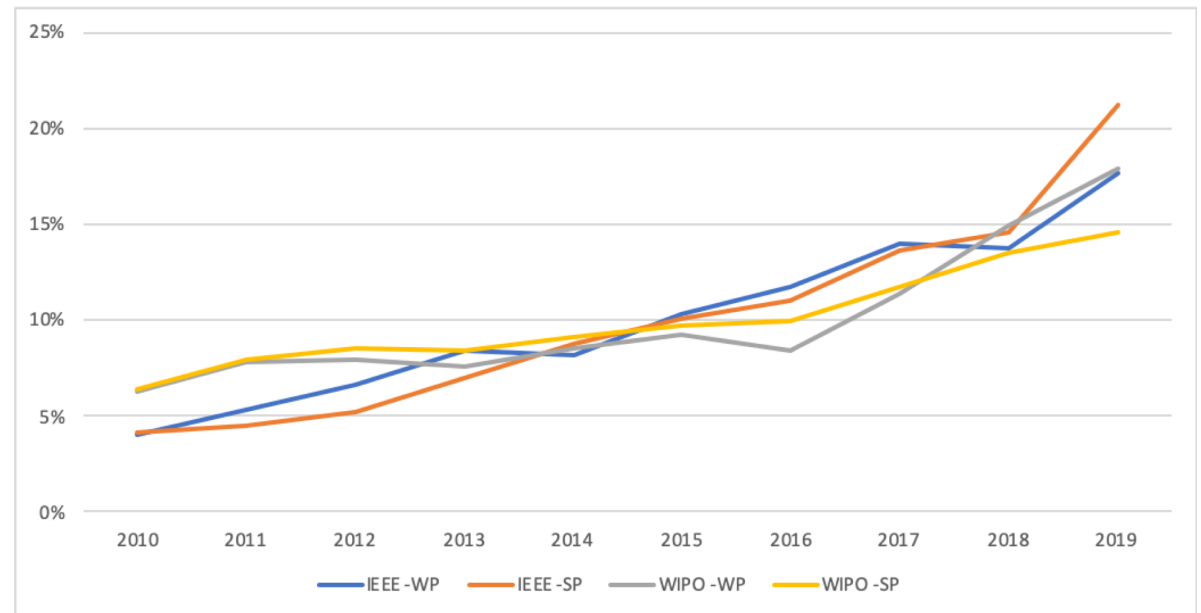

Fig. 6: Important growth observed from IEEE papers and WIPO patents in wind and solar energy 
Table 10. : Frequent words that repeat from 2010 to 2019. Wind Power Search on IEEE database

\begin{tabular}{|c|c|c|c|c|c|c|c|c|c|c|}
\hline & \multicolumn{10}{|c|}{ Year } \\
\hline Words & 2010 & 2011 & 2012 & 2013 & 2014 & 2015 & 2016 & 2017 & 2018 & 2019 \\
\hline analysis & 123 & 150 & 204 & 230 & 245 & 324 & 366 & 524 & 496 & 626 \\
\hline control & 273 & 441 & 409 & 667 & 684 & 794 & 886 & 1314 & 1302 & 1594 \\
\hline converter & 102 & 159 & 193 & 248 & 279 & 321 & 330 & 445 & 430 & 594 \\
\hline design & 112 & 156 & 202 & 237 & 284 & 333 & 372 & 405 & 422 & 516 \\
\hline frequency & 112 & 140 & 228 & 232 & 272 & 345 & 439 & 655 & 619 & 853 \\
\hline generation & 110 & 161 & 282 & 358 & 267 & 401 & 470 & 530 & 606 & 627 \\
\hline generator & 129 & 212 & 233 & 307 & 305 & 326 & 345 & 492 & 430 & 551 \\
\hline grid & 104 & 235 & 223 & 407 & 347 & 397 & 418 & 667 & 541 & 678 \\
\hline model & 221 & 283 & 416 & 503 & 511 & 674 & 814 & 1033 & 1039 & 1539 \\
\hline operation & 110 & 138 & 166 & 222 & 204 & 291 & 369 & 466 & 438 & 651 \\
\hline performance & 105 & 144 & 160 & 222 & 242 & 290 & 363 & 452 & 511 & 654 \\
\hline simulation & 118 & 143 & 168 & 238 & 224 & 281 & 334 & 473 & 413 & 584 \\
\hline speed & 118 & 153 & 219 & 244 & 221 & 276 & 342 & 455 & 411 & 694 \\
\hline systems & 123 & 173 & 195 & 292 & 306 & 372 & 437 & 526 & 608 & 649 \\
\hline winding & 206 & 226 & 292 & 296 & 332 & 457 & 520 & 529 & 581 & 764 \\
\hline & & & & & & & & & & \\
\hline
\end{tabular}

Table 11. : Frequent words that repeat from 2010 to 2019. Solar Power Search on IEEE database

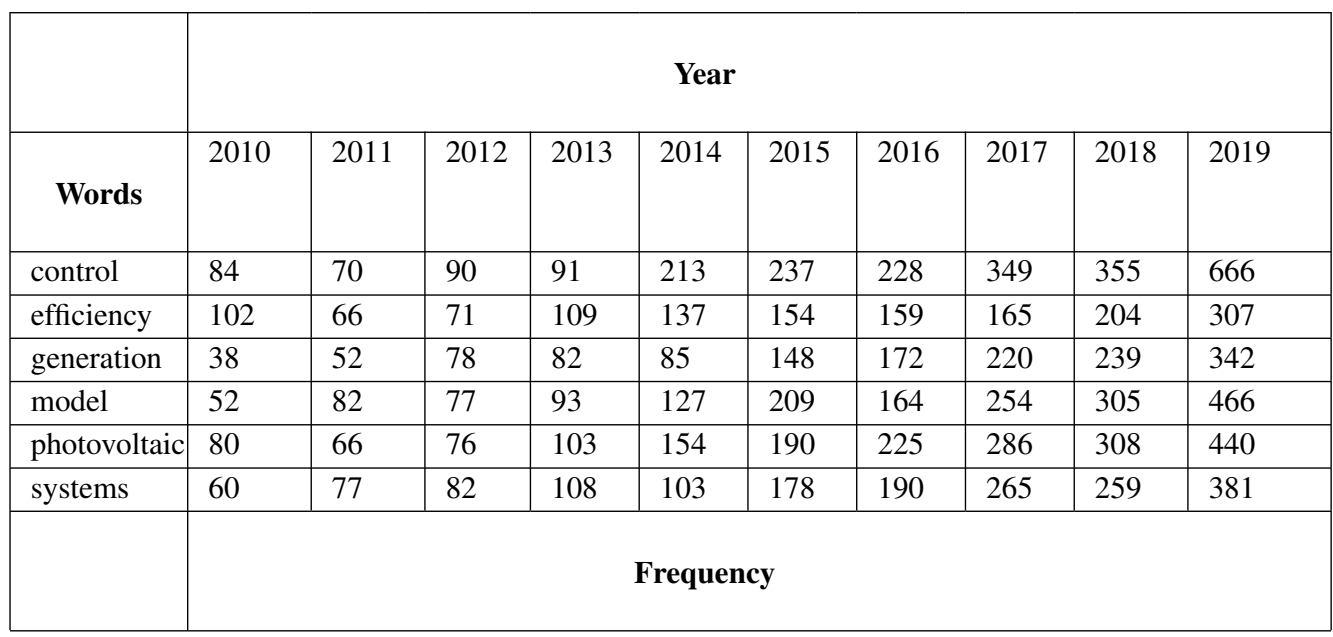

lation between the two types of scientists, inventors and academic ones, and the work that they are producing at the same time. Confirming that, solar power brings nine words in WIPO that are the same as showed in the IEEE extraction, looking at the same period. Revealing that researchers are studying those two renewable energies with many similarities.

\section{CONCLUSIONS}

Renewable energies are becoming the main assets in the modern world. In the last decade, many researchers and companies have invested efforts and resources to find not only new technologies, but also some incremental developments capable of improving relevant solutions and scientific discoveries in two of the most important areas in renewable developments, such as wind and solar 
Table 12. : Papers and patents retrieved from wind and power energy abstracts

\begin{tabular}{|l|l|l|l|l|l|l|l|l|l|l|}
\hline & \multicolumn{9}{|c|}{ Year } \\
\hline & 2010 & 2011 & 2012 & 2013 & 2014 & 2015 & 2016 & 2017 & 2018 & 2019 \\
Database & & & & & & & & & & \\
\hline IEEE-WP & 379 & 503 & 627 & 799 & 782 & 980 & 1112 & 1334 & 1310 & 1682 \\
\hline IEEE-SP & 152 & 163 & 192 & 253 & 319 & 369 & 402 & 496 & 530 & 774 \\
\hline $\begin{array}{l}\text { WIPO- } \\
\text { WP }\end{array}$ & 4262 & 5301 & 5432 & 5157 & 5797 & 6294 & 5686 & 7759 & 10186 & 12190 \\
\hline WIPO-SP & 3801 & 4719 & 5056 & 5001 & 5405 & 5745 & 5919 & 6961 & 8018 & 8599 \\
\hline
\end{tabular}

Table 13. : Unique words that repeat in WIPO and IEEE from 2010 to 2019. Wind Power Search

\begin{tabular}{|c|c|c|}
\hline $\begin{array}{c}\text { Wind } \\
\text { (WIPO/IEEE) }\end{array}$ & WIPO (2019) & IEEE (2019) \\
\hline Word & \multirow{9}{*}{ 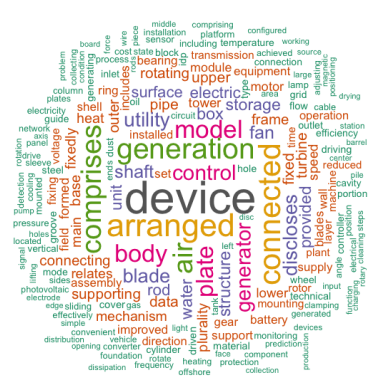 } & \multirow{9}{*}{ 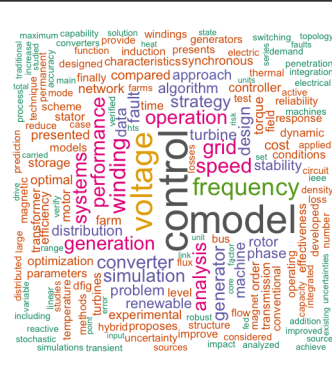 } \\
\hline control & & \\
\hline generation & & \\
\hline generator & & \\
\hline model & & \\
\hline rotor & & \\
\hline speed & & \\
\hline turbine & & \\
\hline voltage & & \\
\hline
\end{tabular}

Table 14. : Unique words that repeat in WIPO and IEEE from 2010 to 2019. Solar Power Search

\begin{tabular}{|c|c|c|}
\hline $\begin{array}{c}\text { Solar } \\
(\text { WIPO/IEEE })\end{array}$ & WIPO (2019) & IEEE (2019) \\
\hline Word & \multirow{10}{*}{ 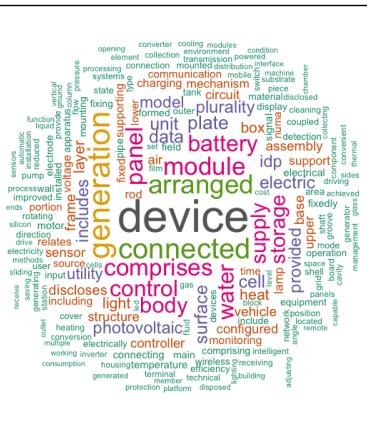 } & \multirow{10}{*}{ 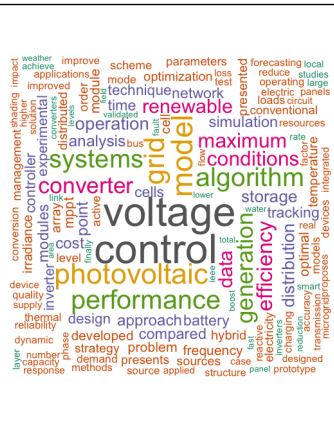 } \\
\hline battery & & \\
\hline cell & & \\
\hline control & & \\
\hline data & & \\
\hline device & & \\
\hline generation & & \\
\hline layer & & \\
\hline photovoltaic & & \\
\hline storage & & \\
\hline
\end{tabular}

energy. Therefore, this paper has proposed a technological trajectory analysis in wind and solar energy, using Rstudio software for applying text-mining techniques in granted patent and patent application documents, retrieved from WIPO database, and papers published by IEEE Xplore Digital Library from 2010 until 2019. This study has shown interesting findings and contributions during this period and important growth observed from IEEE papers and WIPO patents in wind and solar energy solutions.

The results obtained from WIPO patents, for example, particularly extracting the most frequent word cited in wind and solar documents have shown that the inventors and applicants are concerned in solving some objective technical problems, such as the design of wind rotor blades or improve its aerodynamic performance. In addition, these frequent words have disclosed that the word control is in most cases associated to the pitch control of the blade pitch angle. In wind power developments, the study also revealed the top ten patent applicants and that State Grid Corporation of China and General Electric Company are the main companies not only during the past decade, but they will probably be the principal developers in the next years.

This research also shown the top ten applicants in the solar energy inventions and the relevant growing of the Suzhou Csi Solar 
Table 7. : Top ten IPC Code from 2010 to 2019. Solar and Wind Power Search on WIPO database

\begin{tabular}{|l|l|l|l|}
\hline \multicolumn{2}{|c|}{ Wind } & \multicolumn{2}{c|}{ Solar } \\
\hline IPC & Frequency & IPC & Frequency \\
& & & \\
\hline F03D & 23,769 & H02J & 9,094 \\
\hline H02J & 10,141 & H01L & 8,507 \\
\hline H02K & 2,952 & H02S & 6,755 \\
\hline H01M & 2,776 & F24J & 3,514 \\
\hline G06Q & 2,452 & G06F & 2,879 \\
\hline H02P & 2,157 & H01M & 2,350 \\
\hline F03B & 2,056 & G06Q & 2,187 \\
\hline G06F & 2,026 & H02M & 1,846 \\
\hline H02M & 1,728 & H04L & 1,741 \\
\hline H02S & 1,619 & H04W & 1,733 \\
\hline
\end{tabular}

Power Technology Co and Canadian Solar Inc corporations during the past three years. Moreover, it is important to mention that other companies have appeared in this technological scenario in the recent years.

However, China and United States of America are the main applicants for both renewable fields. Finally, the information extracted from patents disclosed that the inventors are working in wind motors, i.e., technologies which covers mechanism for convert energy of wind into useful mechanical power and in solar energy inventions, considering the past 5 years, the applicants have invested in technologies related to the generation electric power using photovoltaic modules and circuit arrangements or systems for supplying or distributing electric power.

These results have been recovered from the patent IPC codes. On the other hand, the results retrieved from IEEE papers have disclosed the main publication titles, wherein the researchers are commonly interested in publishing theirs scientific discoveries. The paper text-mining approach has also shown the main Institutions around the world which is interested to research in wind and solar energies. The Aalborg University, in Denmark, for example, is a great enthusiastic in both renewable technological areas.

Finally, the most frequent words found in paper and patent abstracts have shown that the words model, control, storage, among others, appeared in both databases, which probably is related to the similarities between the context of the researches. However, some words are frequently related to specific studies, since the word device is usually related to patent documents which applicants are concerned to protect inventions, and the words algorithm and simulation, such as shown in the word-clouds, are commonly related to the mathematical approaches for understanding a physical model behavior, before its implementation.

In the future, the authors intend to apply some machine learning techniques to improve the correlations between the words and finding new technological trends in both renewable energies database.
Table 8. : Top twenty publication titles for papers published from solar and wind energy issues

\begin{tabular}{|c|c|c|c|}
\hline \multicolumn{2}{|l|}{ Wind } & \multicolumn{2}{|l|}{ Solar } \\
\hline Publication Title & Freq. & Publication Title & Freq. \\
\hline $\begin{array}{ll}\text { IEEE Transactions } & \text { on } \\
\text { Power Systems } & \end{array}$ & 859 & $\begin{array}{l}\text { IEEE Journal of Photo- } \\
\text { voltaics }\end{array}$ & 448 \\
\hline $\begin{array}{l}\text { IEEE Transactions on Sus- } \\
\text { tainable Energy }\end{array}$ & 701 & $\begin{array}{l}\text { IET Renewable Power } \\
\text { Generation }\end{array}$ & 293 \\
\hline $\begin{array}{l}\text { IET Renewable Power } \\
\text { Generation }\end{array}$ & 688 & $\begin{array}{l}\text { IEEE Transactions on } \\
\text { Power Electronics }\end{array}$ & 222 \\
\hline $\begin{array}{l}\text { IEEE Transactions on In- } \\
\text { dustrial Electronics }\end{array}$ & 585 & $\begin{array}{l}\text { IEEE Transactions on Sus- } \\
\text { tainable Energy }\end{array}$ & 197 \\
\hline $\begin{array}{l}\text { IEEE Transactions on In- } \\
\text { dustry Applications }\end{array}$ & 567 & IEEE Access & 184 \\
\hline $\begin{array}{l}\text { IEEE Transactions on Ap- } \\
\text { plied Superconductivity }\end{array}$ & 562 & $\begin{array}{l}\text { IEEE Transactions on In- } \\
\text { dustry Applications }\end{array}$ & 169 \\
\hline $\begin{array}{l}\text { IEEE Transactions on } \\
\text { Power Electronics }\end{array}$ & 532 & $\begin{array}{l}\text { IEEE Transactions on In- } \\
\text { dustrial Electronics }\end{array}$ & 166 \\
\hline $\begin{array}{l}\text { IEEE Transactions on En- } \\
\text { ergy Conversion }\end{array}$ & 530 & $\begin{array}{l}\text { IEEE Transactions on } \\
\text { Smart Grid }\end{array}$ & 151 \\
\hline $\begin{array}{l}\text { IET Generation, Transmis- } \\
\text { sion \& Distribution }\end{array}$ & 420 & $\begin{array}{l}\text { IEEE Transactions on } \\
\text { Power Systems }\end{array}$ & 122 \\
\hline IEEE Access & 389 & $\begin{array}{l}\text { Monthly Notices of the } \\
\text { Royal Astronomical Soci- } \\
\text { ety }\end{array}$ & 113 \\
\hline $\begin{array}{l}\text { The Journal of Engineer- } \\
\text { ing }\end{array}$ & 375 & $\begin{array}{l}\text { IET Generation, Transmis- } \\
\text { sion \& Distribution }\end{array}$ & 100 \\
\hline $\begin{array}{l}\text { IEEE Transactions on } \\
\text { Power Delivery }\end{array}$ & 361 & IET Power Electronics & 78 \\
\hline $\begin{array}{l}\text { IEEE Transactions on } \\
\text { Magnetics }\end{array}$ & 320 & $\begin{array}{l}\text { IEEE Transactions on En- } \\
\text { ergy Conversion }\end{array}$ & 73 \\
\hline $\begin{array}{l}\text { IEEE Transactions on } \\
\text { Smart Grid }\end{array}$ & 295 & $\begin{array}{l}\text { IEEE Latin America } \\
\text { Transactions }\end{array}$ & 70 \\
\hline $\begin{array}{l}\text { IET Electric Power Appli- } \\
\text { cations }\end{array}$ & 280 & $\begin{array}{l}\text { IEEE Transactions on In- } \\
\text { dustrial Informatics }\end{array}$ & 70 \\
\hline $\begin{array}{l}\text { Monthly Notices of the } \\
\text { Royal Astronomical Soci- } \\
\text { ety }\end{array}$ & 212 & $\begin{array}{l}\text { The Journal of Engineer- } \\
\text { ing }\end{array}$ & 68 \\
\hline IET Power Electronics & 177 & Proceedings of the IEEE & 48 \\
\hline $\begin{array}{l}\text { Journal of Modern Power } \\
\text { Systems and Clean Energy }\end{array}$ & 150 & IEEE Sensors Journal & 45 \\
\hline $\begin{array}{l}\text { IEEE Transactions on Di- } \\
\text { electrics and Electrical In- } \\
\text { sulation }\end{array}$ & 130 & $\begin{array}{l}\text { IEEE Transactions on } \\
\text { Plasma Science }\end{array}$ & 43 \\
\hline $\begin{array}{l}\text { IEEE Journal of Emerg- } \\
\text { ing and Selected Topics in } \\
\text { Power Electronics }\end{array}$ & 129 & $\begin{array}{l}\text { IEEE Journal of Emerg- } \\
\text { ing and Selected Topics in } \\
\text { Power Electronics }\end{array}$ & 42 \\
\hline
\end{tabular}




\section{ACKNOWLEDGMENTS}

The authors are thankful to the Coordenao de Aperfeioamento de Pessoal de Nvel Superior - Brazil (CAPES) and Nove de Julho University (UNINOVE) for their support.

\section{REFERENCES}

[1] Banos, R. et al, Optimization methods applied to renewable and sustainable energy: A review. Renewable and sustainable energy reviews (2011), 15, 1753-1766.

[2] Olajire, A. A. The brewing industry and environmental challenges. In Journal of Cleaner Production (2020), 256, 102817.

[3] U.S. Energy Information Administration. Renewable energy explained. In Monthly Energy Review (2019).

[4] Neill,S.P. et al. Tidal range energy resource and optimizationPast perspectives and future challenges. In Renewable energy (2018), 127, 763-778.

[5] Hand,M. M. et al. Renewable Electricity Futures Study. Volume 1. Exploration of High-Penetration Renewable Electricity Futures. In National Renewable Energy Lab (2012), 1.

[6] Peng,F. et al. Bilateral Coordinated Dispatch of Multiple Stakeholders in Deep Peak Regulation. In IEEE Access (2020), 8, 33151-33162.

[7] Newbery,D. et al. Market design for a high-renewables European electricity system. In Renewable and Sustainable Energy Reviews (2018), 91, 695-707.

[8] Newbery,D. et al. Renewable energy in power systems. In John Wiley \& Sonss (2020), 2, 18-19.

[9] Voe, M.A. The generic challenge: understanding patents, FDA and pharmaceutical life-cycle management. In JBrownWalker Press (2020), 5, 15-119.

[10] Stim, R. Patent, copyright and trademark: an intellectual property desk reference. In Nolo (2020), 16, 7-163.

[11] Fettweis, G. P. The tactile internet: Applications and challenges. In IEEE Vehicular Technology Magazine (2014), 9, 64-70.

[12] Griliches, Z. Patent Statistics as Economic Indicators: A Survey. In University of Chicago Press (1998), 287343.

[13] Pottelsberghe, B. Van. Lost property: the European patent system and why it doesnt work. In Bruegel Blueprint Series (2009), 9, 49-66.

[14] Weiss,S. N.;Indurkhya, N. and Zhang, T. Fundamentals of predictive text mining. In Springer (2015), 13-21.

[15] Dias, C. G. Fuzzy systems applications: a literature review revealed by patents and papers using text mining. In LinkSciencePlace (2018), 5, 125-147.

[16] Neuhusler,P.; Rothengatter, O. and Frietsch, R. Patent Applications - Structures, Trends and Recent Developments. In Studien zum deutschen Innovationssystem, (2019).

[17] Sterlacchin,A. Trends and determinants of energy innovations: patents, environmental policies and oil prices. In Journal of Economic Policy Reform, Taylor \& Francis ( 2019), 49-65.

[18] Albino, V.; Ardito, L.; Dangelico, R. M. and Petruzzelli, A.M. Understanding the development trends of low-carbon energy technologies: a patent analysis. In Applied Energy (2014), 1-19.
[19] Mubarok, M. H.; Nafizah, U. Y. and Perman,M.Y. Mapping technological trajectories of crystalline silicon (c-Si) PV using patent analysis. In International Journal of Renewable Energy Research (2019), 9, 1660-1671.

[20] Verspagen, B. Mapping technological trajectories as patent citation networks: a study on the history of fuel cell research. In Advances in Complex Systems (2007), 93-115.

[21] Fontana, R.; Nuvolari, A. and Verspagen, B. Mapping technologial trajectories as patent citation networks. An application to data communication standards. In Economics of Innovation and New Technology (2009), 311-336.

[22] Kumar,V.; Lai,K-K.; Chang,Y.H. and Lin, C.Y. Mapping technological trajectories for energy storage device through patent citation network. In 9th International Conference on Awareness Science and Technology (iCAST) (2018), 56-61.

[23] Lizin, S. et al. A patent landscape analysis for organic photovoltaic solar cells: identifying the technology's development phase. In Renewable Energy (2013), 57, 5-11.

[24] Sampaio, P. G. V. et al. Photovoltaic technologies: Mapping from patent analysis. In Renewable and Sustainable Energy Reviews (2018), 93, 215-224.

[25] Singh, G. K. Solar power generation by PV (photovoltaic) technology: a review. In Energy (2013), 53, 1-13.

[26] Cheng, M. and Zhu, Y. The state of the art of wind energy conversion systems and technologies: a review. In Energy Conversion and Management (2014), 88, 332-347.

[27] Aleixandre-Tud, J.L. et al. Renewable energies: Worldwide trends in research, funding and international collaboration. In Renewable energy (2019), 139, 268-278.

[28] Patents Analysis of Thermal Bridges in Slab Fronts and Their Effect on Energy Demand. In Energies, (2018), 11, 2222.

[29] Patent Analysis of High Efficiency Tunneling Oxide Passivated Contact Solar Cells. In Energies, (2020), 13, 3060.

[30] Dias, C.G and Morais de, A.M. Analises da Trajetoria Tecnologia da Energia Elica a Partir de Tcnicas de Minerao de Textos em Patents. In Sodebras Conference - Brazil, (2020), 1-5.

[31] Graham, R. The global state of the art in engineering education, Massachusetts Institute of Technolog. In Massachusetts Institute of Technology, (2018), 1-162. 